\title{
'Pele de sapo' melon grown under different irrigation depths and bioestimulant rates in the Semiarid region of Brazil
}

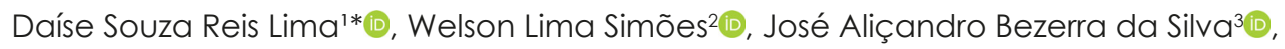

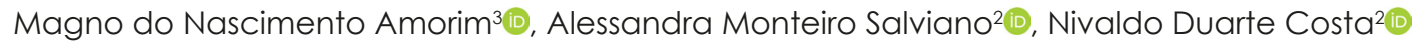 \\ 'Faculty of Technology and Sciences - UNIFTC, Juazeiro, Brazil \\ ${ }^{2}$ Embrapa Semiarid, Petrolina, Brazil \\ ${ }^{3}$ Federal University of São Francisco Valley, Juazeiro, Brazil \\ *Corresponding author, e-mail: dayse29@hotmail.com
}

\begin{abstract}
The objective of this work was to evaluate physiological and biochemical responses of Pele de sapo melon to different irrigation depths (ID) and bioestimulant rates (BTM) to improve its production efficiency. The experiment was conducted in an experimental field in Juazeiro, BA, Brazil. A randomized block design in split split-plot arrangement was used, with four ID $(60,80,100$, and $120 \%$ of crop evapotranspiration - ETC) in the plots; five (BTM) (Stimulate ${ }^{\oplus}$ at $0,0.6,1.2,2.4$, and $4.8 \mathrm{~L} \mathrm{ha}^{-1}$ applied via irrigation system during the flowering stage and after the fruiting stage) in the subplots; and two crop seasons (hot season, 23 to $39^{\circ} \mathrm{C}$; and cold season, 15 to $30^{\circ} \mathrm{C}$ ) in the sub-subplots. The plants were under daily drip irrigation and spacing of $2.0 \times 0.3 \mathrm{~m}$. The variables evaluated were: gas exchange, water use efficiency, chlorophyll $a$ and $b$, relative water, sugar, and amino acid contents, and fruit yield. The results showed that the ID of $60 \%$ ETc resulted in water deficit, denoted by increases in solute concentrations, whereas the ID of $80 \%$ and $100 \%$ resulted in plants with good performance for biochemical, physiological, and production parameters in both crop seasons. The hot season, ID of 120\% ETC, and BTM of $2.4 \mathrm{~L} \mathrm{ha}^{-1}$ are recommended for Pele de sapo melon crops, since they result in the best physiological responses and fruit yields.
\end{abstract}

Keywords: Cucumis melo, irrigation management, water deficit

\section{Introduction}

Melon (Cucumis melo) crops in Brazil has been increasing in the last two decades, with an increase in fruit production from 350,000 in 2002 to $600,000 \mathrm{Mg}$ in 2016. It has a high socioeconomic importance for the Northeast region of Brazil, concentrating $95 \%$ of the national production. The Pele de sapo melon, is the second most produced melon variety in the region due to its large fruits, good pulp firmness, and greenish color (Figueirêdo et al., 2017; Dantas et al., 2013).

Juazeiro, BA, is the third largest agricultural region of the Northeast of Brazil, comprising mainly small farmers; its main crop season is from February to April due to the better temperature conditions $\left(27\right.$ to $33^{\circ} \mathrm{C}$ ) (Araújo et al., 2008). According to Costa (2008), these are the ideal ranges for melon production.

The other crop seasons present different characteristics, which is a challenge for melon producers that focus on maximizing production and fruit quality. However, according to Câmara et al. (2007), an adequate management based on climate characteristics of the seasons can be an alternative to increase melon yield and improve the crop economic value in these seasons.

Thus, the use of irrigation in semiarid regions, which present low water availability, is essential to an adequate water supply, mainly for melon species, which present high water demand (300 to $550 \mathrm{~mm}$ ) (Araújo \& Deminicis, 2009). The adequate water status of melon plants by using ideal irrigation depths (ID) results in good performance of physiological, biochemical, morphological, and productive parameters, and in a satisfactory production cycle (Suassuna et al., 2011).

Water availability varies in semiarid regions; thus, the use of different bioestimulant rates (BTM) has been studied for capacity of interference on plant growth and development processes, which has improving nutrient 
absorption, hormonal activity efficiency, tolerance to stresses, and fruit quality and yield (Calvo et al., 2014). Therefore, evaluating these plant growth regulators is important for Pele de sapo melon crops to minimize deleterious effects of climate conditions and water stress (Abrantes et al., 2011).

Considering the need for adequacy of Pele de sapo melon crops systems in new producing regions such as the Semiarid in Brazil, the objective of this work was to evaluate physiological and biochemical responses of Pele de sapo melon to different ID and BTM to improve its production efficiency in low water availability regions.

\section{Material and Methods}

The experiment was conducted in an area of $448.5 \mathrm{~m}^{2}$ of the experimental farm of the Brazilian Agricultural Research Corporation (Embrapa Semiarid), at the Mandacaru irrigation project area, in Juazeiro, BA, Brazil $\left(09^{\circ} 24^{\prime} \mathrm{S}, 40^{\circ} 26^{\prime} \mathrm{W}\right)$. The climate of the region is BSwh', according to the Köppen classification, with high temperatures, scarce and irregularly distributed rainfall, concentrated in November to April, with annual mean depth of approximately $500 \mathrm{~mm}$ (Lopes, 2014).

The experiments were conducted in two crop seasons: hot season from September to November 2016 , with higher temperatures $\left(23\right.$ to $\left.39^{\circ} \mathrm{C}\right)$ and solar radiation; and cold season from May to July 2017, with lower temperatures ( 15 to $30^{\circ} \mathrm{C}$ ) and solar radiation.

The soil of the area was classified as a Typic Hapludert. Soil fertilization, via fertigation, was carried out based on soil analyses (Table 1), using $145 \mathrm{~kg} \mathrm{ha}^{-1}$ of N, 60 $\mathrm{kg} \mathrm{ha}^{-1}$ of $\mathrm{P}_{2} \mathrm{O}_{5^{\prime}}$ and $125 \mathrm{~kg} \mathrm{ha}^{-1}$ of $\mathrm{K}_{2} \mathrm{O}$ in the hot season, and $184 \mathrm{~kg} \mathrm{ha}^{-1}$ of $\mathrm{N}, 60 \mathrm{~kg} \mathrm{ha}^{-1}$ of $\mathrm{P}_{2} \mathrm{O}_{5}$ and $155 \mathrm{~kg} \mathrm{ha}^{-1}$ of $\mathrm{K} 2 \mathrm{O}$ in the cold season. The fertilizer sources were urea $(\mathrm{N})$, monoammonium phosphate $\left(\mathrm{P}_{2} \mathrm{O}_{5}\right)$, and potassium sulfate $\left(\mathrm{K}_{2} \mathrm{O}\right)$. Topdressing started at 22 days after the transplant of the seedlings, divided into two applications per week, for five weeks.

Table 1. Soil chemical characteristics, in two crop season (CS) of Pele de sapo melon, hybrid Juazeiro.

\begin{tabular}{|c|c|c|c|c|c|c|c|}
\hline Soil layers & $\mathrm{pH}$ & $\begin{array}{l}\text { Organic matter } \\
\qquad \mathrm{g} \mathrm{kg}^{-1}\end{array}$ & $\begin{array}{c}\mathrm{P} \\
--\mathrm{mg}\end{array}$ & $\begin{array}{l}\mathrm{Na}^{+} \\
\mathrm{dm}^{-3}--\end{array}$ & $\begin{array}{c}\mathrm{K}^{+} \\
---\mathrm{Cm}\end{array}$ & $\begin{array}{l}\mathrm{Ca}^{2+} \\
\mathrm{Ool}_{\mathrm{C}} \mathrm{dm}\end{array}$ & $\mathrm{Mg}^{2+}$ \\
\hline $0-20$ CS 1 & 7.4 & 12.6 & 17 & 0.39 & 1.76 & 35.1 & 8.1 \\
\hline $20-40$ CS 1 & 7.5 & 6.8 & 11 & 0.30 & 0.31 & 35.8 & 8.3 \\
\hline $0-20$ Cs 2 & 7.2 & 8.4 & 19 & 0.19 & 0.23 & 30.0 & 9.3 \\
\hline $20-40$ CS 2 & 7.5 & 6.2 & 15 & 0.22 & 0.17 & 32.4 & 7.6 \\
\hline
\end{tabular}

The soil preparation consisted of one plowing, one harrowing, furrowing for the planting rows, and furrowing for pre-planting soil fertilization. After the first soil fertilization, the beds were raised mechanically and adjusted manually. Subsequently, the irrigation system was assembled, and the soil was covered with black mulching. Cultural practices during the experiment consisted of pesticide applications to control phytopathogens, and cleaning of the area, when required.

Melon seeds of the variety Pele de sapo, hybrid Juazeiro, were sowed in 200-cell polyethylene trays. The seedlings were transplanted at 10 days after seeding to the experimental area and planted with spacing of 2.0 $\times 0.3 \mathrm{~m}$.

A localized drip irrigation system was used, with drippers distributed in the planting rows with emitters spaced $0.3 \mathrm{~m}$ apart, with flow rate of $2.5 \mathrm{~L} \mathrm{~h}^{-1}$. The irrigation depths (ID) were calculated based on the Penman Monteith method using climate data from a meteorological station installed next to the experiment site. The crop coefficients $(\mathrm{KC})$ used were 0.35, 0.7, 1.0, and 0.8 for the initial, vegetative, fruiting, and maturation stages, respectively, which were adapted to the crop conditions of the area, according to recommendations of Miranda \& Bleicher (2001).

The experiment was conducted in a randomized block design, with split split-plot arrangement and four replications, consisting of four ID $(60,80,100$, and $120 \%$ of crop evapotranspiration - ETc) in the plots of 120 plants, five bioestimulant rates (BTM) Stimulate ${ }^{\circledR}$ at $0,0.6,1.2$, 2.4 , and $4.8 \mathrm{~L} \mathrm{ha}^{-1}$ applied via irrigation system during the flowering stage and after the fruiting stage) in the subplots of 30 plants, and two crop seasons (hot season, $23^{\circ}$ to $39{ }^{\circ} \mathrm{C}$; and cold season, 15 to $30^{\circ} \mathrm{C}$ ) in the sub-subplots, totaling 480 plants per crop season. The experimental plot consisted of six plants, considering the four central plants for the evaluations.

The plant bioestimulant used (Stimulate ${ }^{\circledR}$; Stoller do Brasil Ltda., Cosmópolis, Brazil) was a liquid composed of three growth regulators: $90 \mathrm{mg} \mathrm{L}^{-1}$ cinetin (cytokinin), $50 \mathrm{mg} \mathrm{L}^{-1}$ of indole butyric acid (auxin), and $50 \mathrm{mg} \mathrm{L}^{-1}$ of gibberellic acid (gibberellin). Three applications of the product were carried out, via irrigation system, at the beginning of male flowering, at the end of female flowering, and when the fruits were with approximately $54 \mathrm{~mm}$ diameter.

The chlorophyll index was determined at 40 days after germination, using a portable Falker ClorofiLOG device (CFL-1030), with non-destructive leaf measurements, quantifying the chlorophyll $a$ and $b$ indexes.

The relative water content was determined at 41 days after germination using discs of mature leaves, following the methodology of Marenco et al. (2009).

Physiological analyses and leaf collection for 
biochemical analyses were carried out at 45 days after germination. The variables evaluated were: photosynthetic rate, stomatal conductance, internal $\mathrm{CO}_{2}$ concentration, leaf transpiration, and leaf temperature, through readings with a photosynthesis meter portable device infrared gas analyzer (Li-6400, Licor Inc., Lincoln, USA). The quotient between photosynthetic rate and leaf transpiration was used to determine the water use efficiency in the gas exchanges.

Total soluble sugar (TSS) contents were evaluated according to the methodology described by Moris (1948) and Yemm \& Willis (1954) using the anthrone reagent. Reducing sugars (RS) were evaluated using the 3,5-dinitrosalicylic acid method proposed by Miller (1959) with spectrophotometric readings of the wavelengths of 620 and $540 \mathrm{~nm}$ for TSS and RS, respectively.

The amino acid contents were determined by testing the reactions using the ninhydrin reagent as described by Cocking \& Yemm (1954), determining a standard curve using a solution with known concentration and absorbance readings in spectrophotometer in the wavelength of $570 \mathrm{~nm}$.

The commercial fruit yield of the evaluated plants of each treatment was quantified at harvest.

The data of the variables were subjected to analysis of variance by the $\mathrm{F}$ test $(p<0.05)$. The effects of quantitative factors (ID and BTM) were evaluated by regression analysis, testing linear and quadratic models $(p<0.05)$. When the interaction between crop seasons and the other factors was not significant, the data of crop seasons were compared by the Tukey's test $(p<0.05)$. All analyses were carried out using the Sisvar 7.7 program (Ferreira, 2011).

\section{Results and Discussion}

Evapotranspiration, temperature, and solar radiation were lower from May to June 2017, in the cold season (Figure 1A). The mean solar radiation from September to November 2016 in the hot season was 23.36

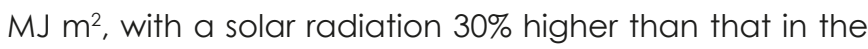
cold season (Figure 1B).

Relative water content was higher in the hot season in plants grown without bioestimulant application and under irrigation depth (ID) of $120 \%$ ETc (Figure 2A), showing that the irrigation is the main factor for leaf water transport and accumulation. Thus, water available in the rhizosphere increases as the ID increases; the hot season probably promoted higher leaf transpiration rates and consequently a probable higher leaf water flux, increasing the cell turgidity (Figure 2A).
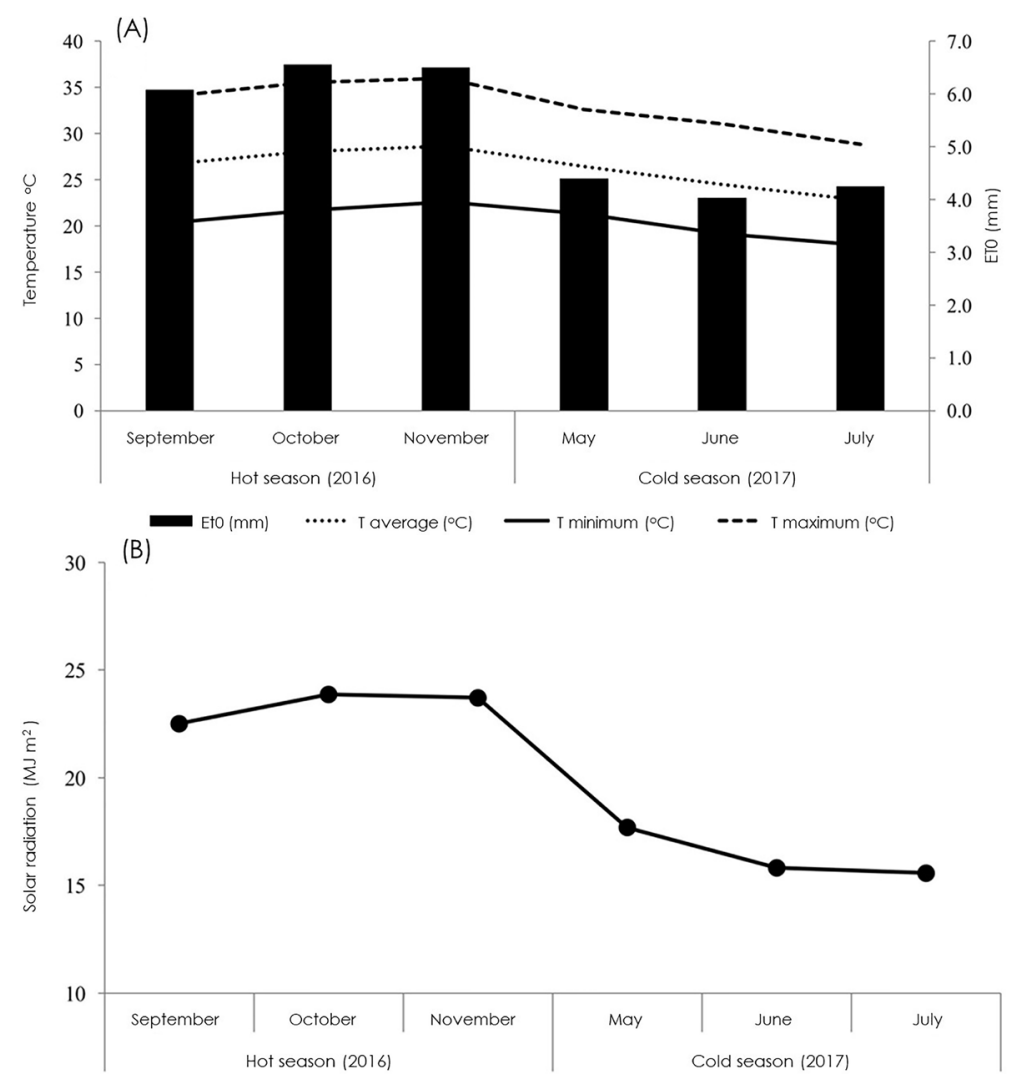

Figure 1. Monthly reference evapotranspiration $\left(\mathrm{ET}_{0}\right)$, and mean, maximum, and minimum temperatures (A); and monthly solar radiation (B) in two crop seasons. Data from a meteorological station next to the experiment site, Juazeiro, BA, Brazil. 

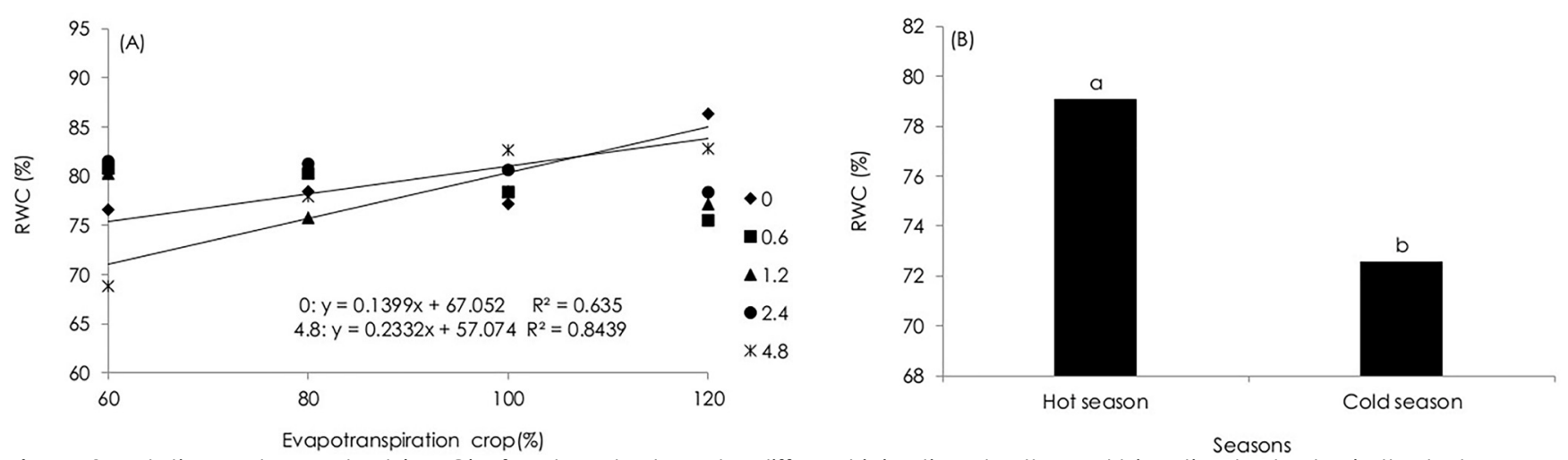

Figure 2. Relative water content (RWC) of melon plants under different irrigation depths and bioestimulant rates in the hot season.

Similar results were reported by Soares et al (2012), who evaluated ID in tomato crops and found increase of $10.61 \%$ in leaf water content as the ID was increased from $60 \%$ to $120 \%$ ETc. According to Beltrano \& Ronco (2008), increases in available water content for the root system results in a higher water absorption per plant and, consequently, higher water content in the intercellular spaces, thus increasing leaf cell turgidity.

The relative water content was lower in the cold season (Figure 2B), probably due to the low leaf transpiration caused by the lower temperature and evapotranspiration conditions in this crop season (Figure 1), which may have decreased the water flux from roots to the leaves.

Chlorophyll $a$ and $b$ indexes were not significantly affected by the ID and bioestimulant rates (BTM) (Figures $3 A$ and $B$ ), but varied between crop seasons, which was also caused by the higher photosynthetic activity due to the higher solar radiation in the hot season (Figure 1).

This reaction may explain the increases in chlorophyll b accumulation in the cell chloroplasts in the cold season, which presented decreases in photosynthetic activity due to the lower temperature and solar radiation and, consequently, conversion of chlorophyll $a$ into chlorophyll b.

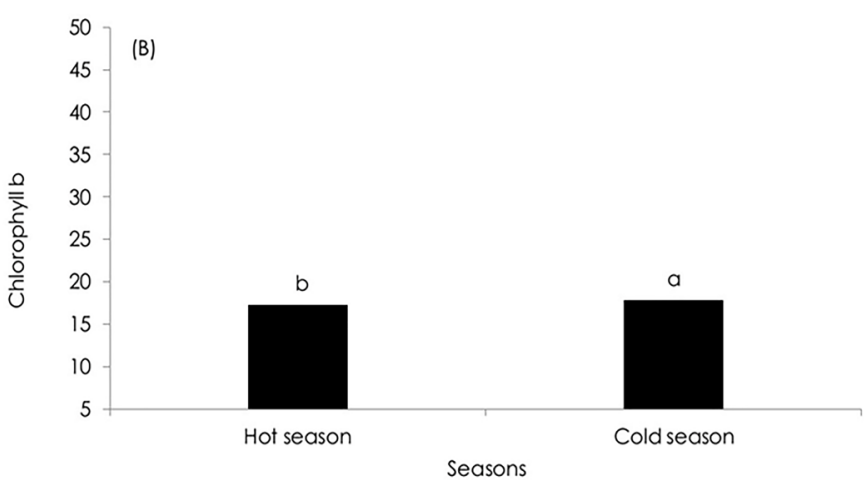

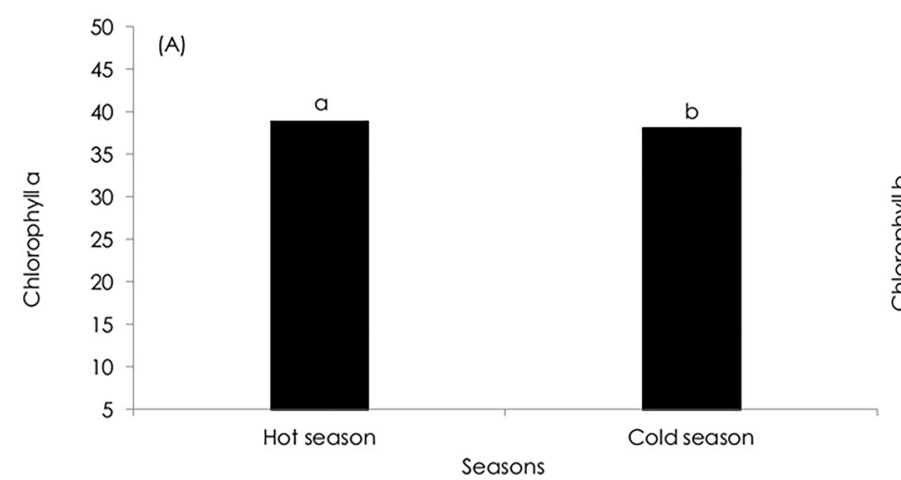

Figure 3. Chlorophyll $a(A)$ and $b(B)$ in melon leaves grown in the hot and cold seasons under different irrigation depths and bioestimulant rates.

The plants grown in the hot season had higher photosynthetic activity (Figure 4A), with better results for the ID 100\% ETC without application of bioestimulant. However, photosynthetic activity tends to increase as the ID are increased. This increase in water demand may result in a lower sugar concentration in the fruits, and decrease economic gains, considering the productive potential of the plants.

Figure 4 shows a gradual increase for ID in the hot season, which resulted in higher stomatal conductance rates, leaf transpiration $(E)$, and internal $\mathrm{CO}_{2}$ concentration. The interaction between ID and BTM in the hot season showed increases in gas exchange up to the ID of $120 \%$ ETC for photosynthetic rate $(A)$ and stomatal conductance (gs), and a trend of increase for all BTM as the ID were increased.

These results show that the main factor is the increases in $\mathrm{CO}_{2}$ uptake due to the higher stomatal opening. In addition, the transpiration rate increased and, consequently, the $\mathrm{CO}_{2}$ accumulation in the mesophyll.

Dalastra et al. (2014) evaluated three varieties of Pele de sapo melon and found $\mathrm{A}$ of $26.54 \mu \mathrm{mol} \mathrm{CO} 2 \mathrm{~m}^{-2}$ $\mathrm{s}^{-1}$, and $E$ of $8.08 \mathrm{mmol} \mathrm{H}_{2} \mathrm{O} \mathrm{m}^{-2} \mathrm{~s}^{-1}$ for the hybrid Sancho. According to Chaves et al. (2015), these differences are common when comparing different crop seasons and local climate conditions. Silva et al. (2015) evaluated 
different ID on eggplant crops grown under protected environment and found higher internal $\mathrm{CO}_{2}$ concentration (Ci), A, gs, and E for the highest ID (160\% ETC).

Dalastra et al. (2014) found lower internal $\mathrm{CO}_{2}$

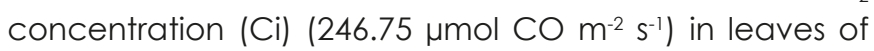
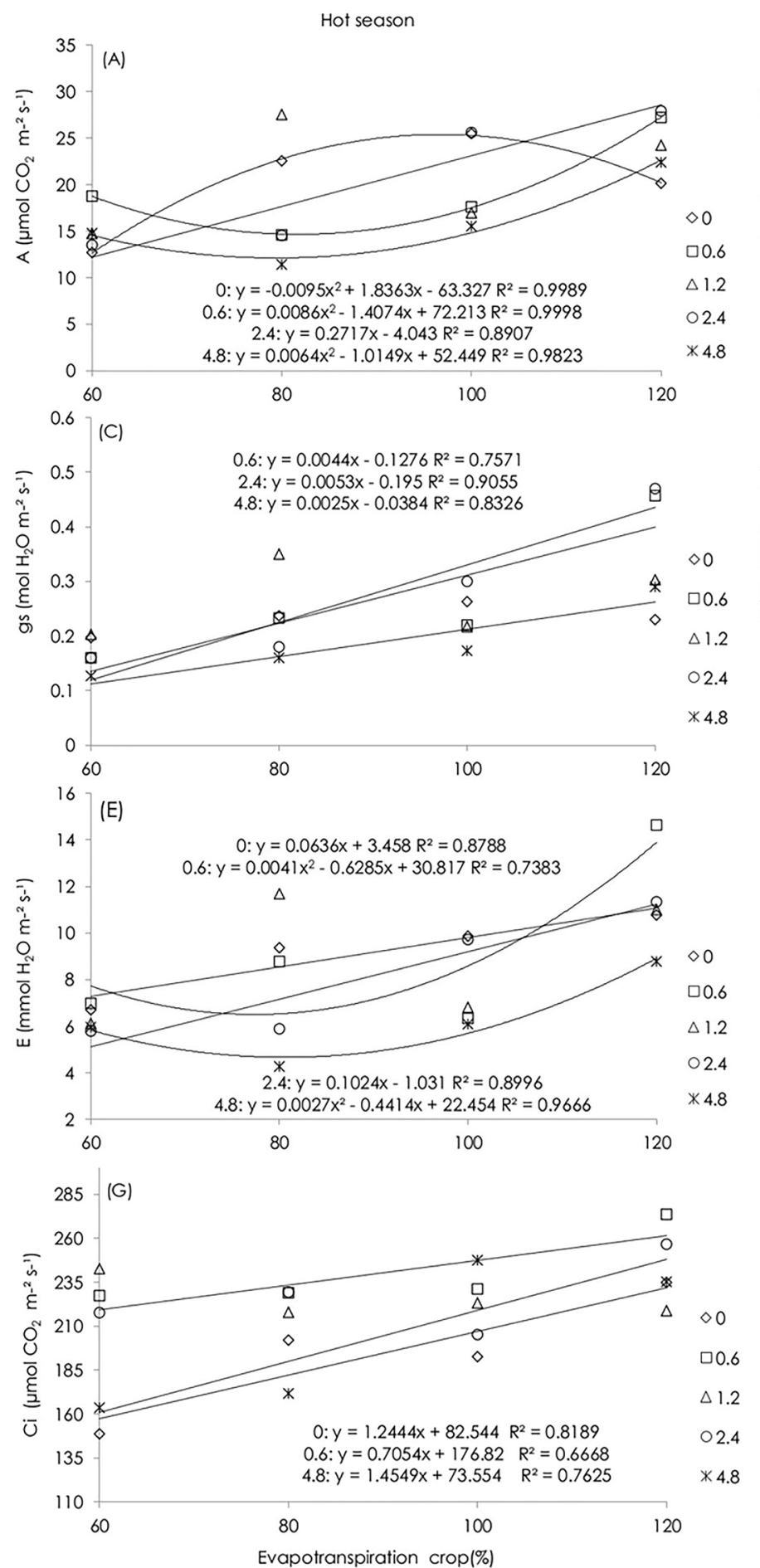

Pele de sapo melon. This denotes that the bioestimulant was efficient in increasing gas exchange reactions under the experimental conditions in the present work, resulting in a better metabolic performance of melon plants in the highest ID used.
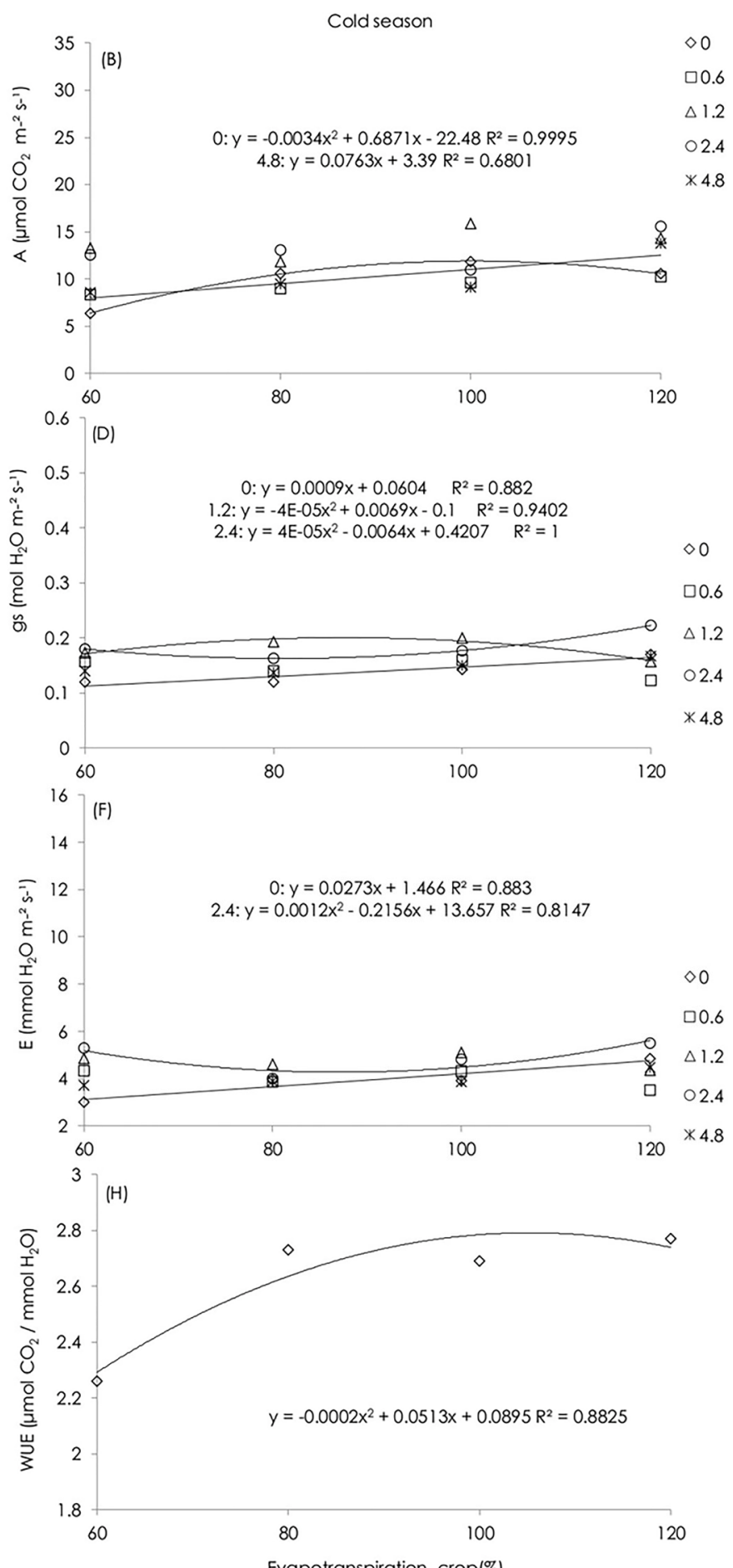

Figure 4. Photosynthetic rate $(A)$, stomatal conductance $(g s)$, leaf transpiration $(E)$, internal $\mathrm{CO}_{2}$ concentration $(C i)$, and water use efficiency (WUE) of Pele de sapo melon plants grown in the hot ( $A, C, E$, and $G$ ) and cold $(B, D, F$, and $H$ ) seasons, under different irrigation depths and bioestimulant rates.

In the cold season, the use of ID of $120 \%$ ETc and BTM of $4.8 \mathrm{~L} \mathrm{ha}^{-1}$ resulted in significant lower $\mathrm{A}$ than the rate 0 (Figure $4 B$ ), however lower than that found in the hot season. The rate of $2.4 \mathrm{~L} \mathrm{ha}^{-1}$ resulted in higher gs $(0.223$ $\left.\mathrm{mol} \mathrm{H}_{2} \mathrm{O} \mathrm{m}^{-2} \mathrm{~s}^{-1}\right)$ in the ID $80 \% \mathrm{ETC}$, and higher $\mathrm{E}(5.5 \mathrm{mmol}$ $\mathrm{H}_{2} \mathrm{O} \mathrm{m}^{-2} \mathrm{~s}^{-1}$ ) in the ID of $89 \%$ ETc (Figures $4 \mathrm{D}$ and $4 \mathrm{~F}$ ). These 
responses are related to increases in stomatal opening, which allows a higher $\mathrm{CO}_{2}$ uptake and accumulation in mesophyll cells, and increases in transpiration.

In the cold season, the photosynthetic activity and the water use efficiency tended to decrease when using the highest ID (Figure $4 \mathrm{~B}$ and $4 \mathrm{H}$ ), whereas gs and $E$ presented little variation as the ID was increased (4D and $4 \mathrm{~F}$ ). This change may be explained by the lower solar radiation and, consequently, lower light incidence on the leaves in this season.

Thesereactionsmayhavecaused alowerstomatal
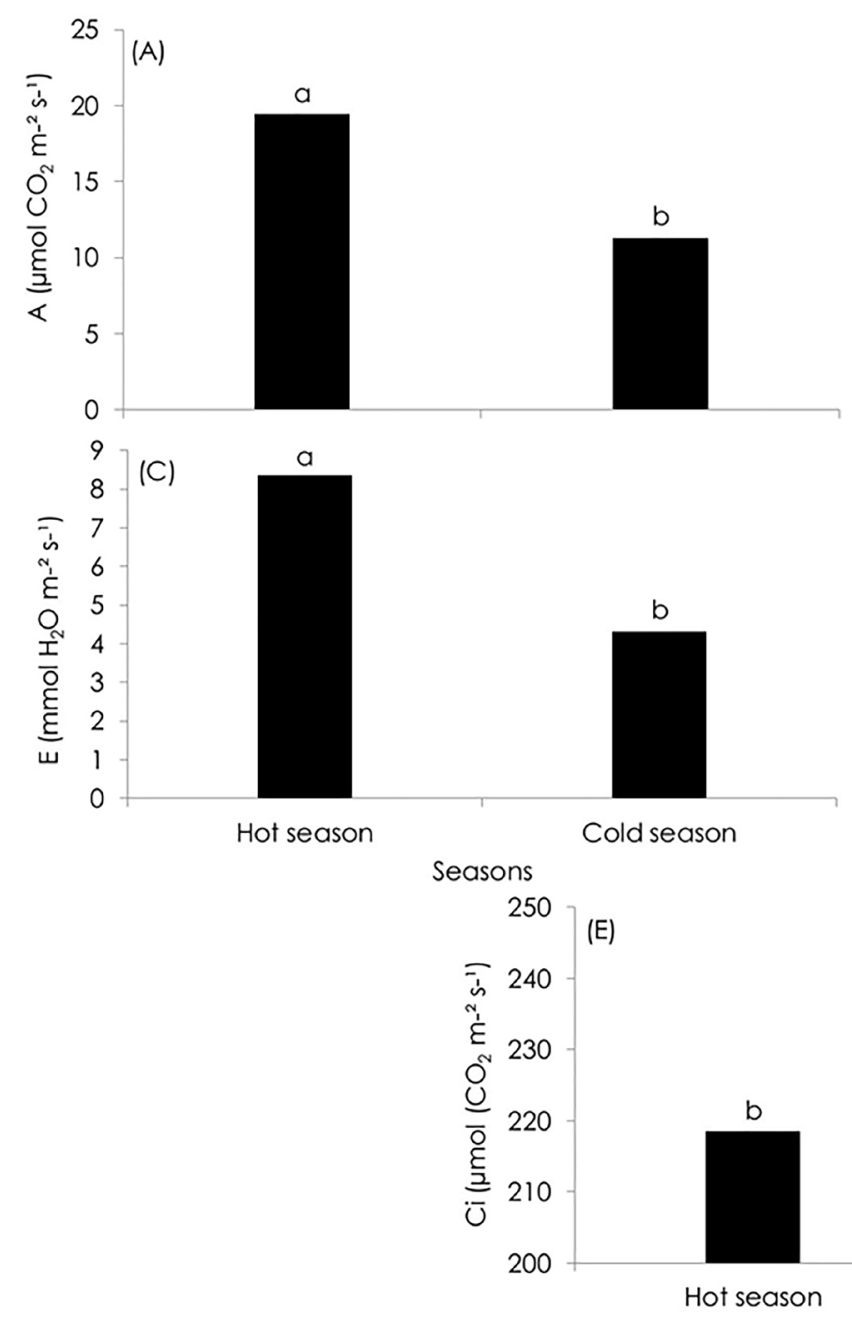

opening, lower transpiration and, consequently, lower access of atmospheric $\mathrm{CO}_{2}$ to mesophyll cells, resulting in lower $\mathrm{CO}_{2}$ metabolism during the photochemical stage of the photosynthesis. The decreases in the highest ID may be related to excess soil water, which hinders physiological reactions and root system development of plants.

The efficiency in the physiological reactions of plants is related to different seasonal factors, since A, gs, $E$, and leaf temperature (LT) were higher in the hot season (Figure 5).
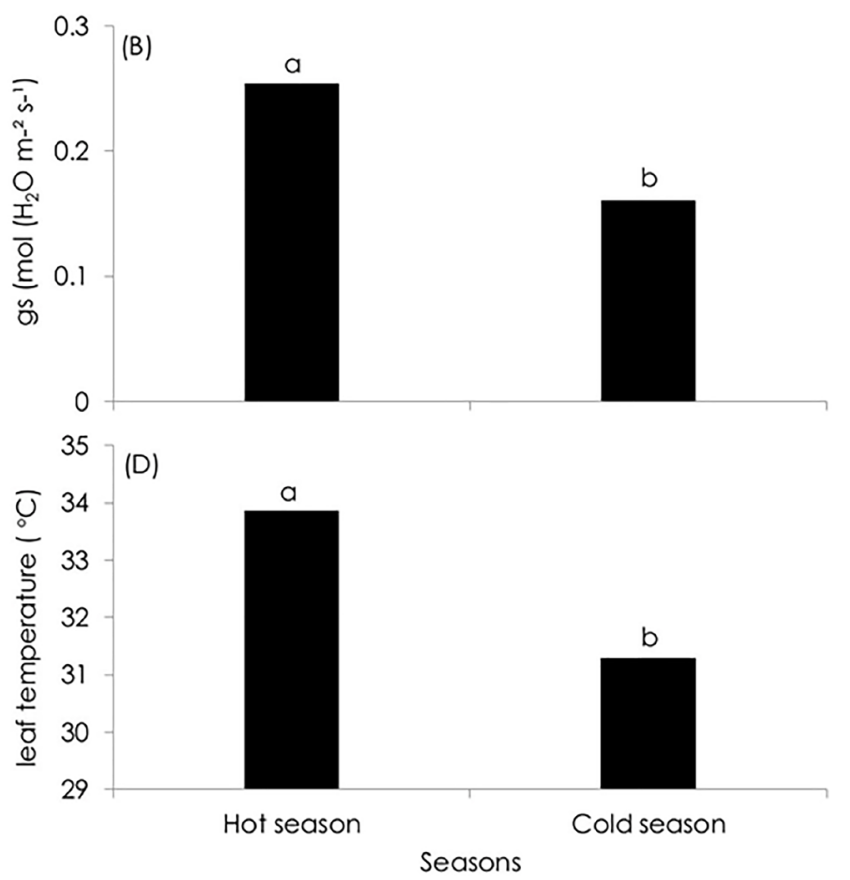

a

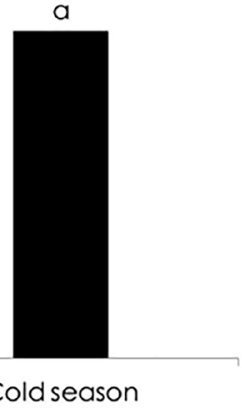

Seasons

Figure 5. Photosynthetic rate (A), stomatal conductance (gs), leaf transpiration (E), leaf temperature (LT), and internal $\mathrm{CO}_{2}$ concentration (Ci) of Pele de sapo melon plants grown under different irrigation depths and bioestimulant rates in the hot and cold seasons.

These responses were probably affected by climate variables during the crop seasons, since solar radiation and temperature were higher in the hot season (Figure $1 \mathrm{~A}$ and 1B). According to Araújo \& Deminicis (2009), light is the main factor (energy source) that triggers photochemical reactions.

The higher solar radiation and temperature in the hot season (Figure 1A) might have increased the stomatal opening frequency, transpiration, $\mathrm{CO}_{2}$ uptake, and cytoplasm and stroma solubility. Contrastingly, solar radiation and temperature were lower in the cold season, decreasing leaf transpiration and, consequently, $\mathrm{CO}_{2}$ uptake and photosynthetic activity. This was probably due to decreases in electron flux by protein and non-protein compounds in the thylakoid membranes responsible for electron transport. 
Regarding the higher $\mathrm{Ci}$ index found in the cold season (Figure $5 \mathrm{E}$ ), the lower temperature in the cold season may have caused a higher $\mathrm{CO}_{2}$ concentration in the cytoplasm and stroma of chloroplasts.

Although the mean leaf temperature was 31.28 ${ }^{\circ} \mathrm{C}$ in the cold season (Figure 5D), it was within the ideal range for melon crops $\left(25\right.$ to $35^{\circ} \mathrm{C}$ ) and, according to Costa (2008), favorable to the crop development.

Machado et al. (2010) found decreases of $32 \%$ and $22 \%$ in daily photosynthetic activity in orange rootstocks subjected to nocturnal temperature of $8{ }^{\circ} \mathrm{C}$ for 12 hours, when compared to those under $20^{\circ} \mathrm{C}$ for 12 hours, and reported a direct action of low temperatures on stomatal closure and, consequently, decreases in photosynthetic rates.

According to Costa (2008) melon crop present good development in semiarid climate regions, but is sensitive to periods of low temperatures. Machado et al. (2013) reported that the gas exchange and carbohydrate translocation of plants with these characteristics can be inhibited when exposed to mild temperatures, decreasing their growth rate and development.

The results of the biochemical variables are represented in Figure 6, which shows the significant interaction between ID and BTM for total soluble sugar (TSS), reducing sugar (RS), and amino acid (AAC) contents, in both crop seasons.

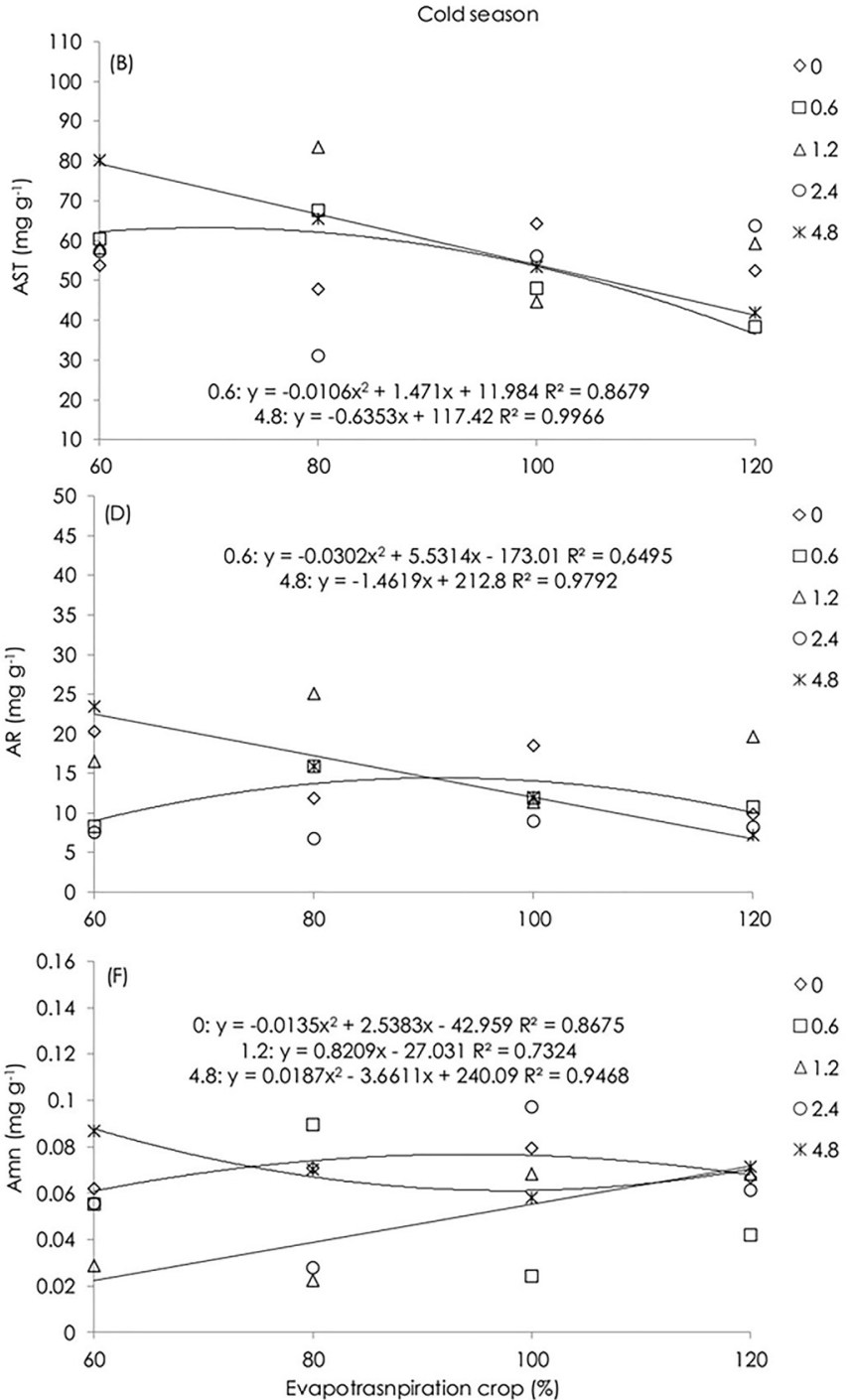

Figure 6. Total soluble sugar (TSS), reducing sugar (RS), and amino acid (AAC) contents in Pele de sapo melon plants grown under different irrigation depths and bioestimulant rates in the hot (,$C$, and $E$ ) and cold $(C, D$, and F) seasons.

The BTM of $0.6 \mathrm{~L} \mathrm{ha}^{-1}$ with ID of $60 \%$ ETC favored leaf TSS accumulation in the hot season (Figure 6A). This showing that the low BTM may have affected defense mechanisms of the plants subjected to water stress, since the same BTM had no significant effect to photosynthetic activity and water use efficiency (Figure 3).

The TSS accumulation is explained by the plants' leaf osmotic adjust capacity under low water availability; 
they concentrate more solutes in the cell to maintain the leaf tissue turgidity required for the plant development (Pereira et al., 2012). However, the limitation of water supply to plants when using the ID of $60 \%$ ETc decreased the water in the cell cytoplasm and organelles, increased solute concentration in the cells and tissues and, consequently, in the whole plant.

The highest BTM (4.8 $\left.\mathrm{L} \mathrm{ha}^{-1}\right)$ with ID of $60 \%$ ETC resulted in higher TSS $\left(80.2 \mathrm{mg} \mathrm{g}^{-1}\right)$ in the cold season (Figure 6B). Thus, a higher BTM may have promoted metabolic reactions that produce solutes, increasing their concentration inside the cell. This is due to environmental stress caused by the less favorable climate conditions to the crop in this season, such as low temperatures and high relative humidity.

The interaction between the factors was significant for RS in both crop seasons (Figure 6C and 6D). The BTM of $2.4 \mathrm{~L} \mathrm{ha}^{-1}$ with ID of $100 \%$ ETC in the hot season resulted in higher RS mean (42.16 $\left.\mathrm{mg} \mathrm{g}^{-1}\right)$, denoting higher sugar contents (Figure 6C). Contrastingly, the cold season had lower RS concentrations (Figure 6D). This may be due to reductions of TSS into saccharoses, which decreased as the ID was increased due to their break in the leaf, thus increasing RS contents in glycose form.

The interaction between the factors was significant for AAC in both crop seasons (Figure 6E and 6F). In the hot season, AAC decreased linearly as the ID and BTM were increased. This was due to increases in soil water availability, which intensifies water translocation to the shoot, increasing the leaf water potential and decreasing solute concentration (Lechinoski et al., 2007).
Thus, higher AAC values were found for the lowest ID applied (60\% ETC), with mean of $0.130 \mathrm{mg} \mathrm{g}^{-1}$ for the BTM of $2.4 \mathrm{~L} \mathrm{ha-1} \mathrm{(Figure} \mathrm{6E).} \mathrm{Almeida} \mathrm{et} \mathrm{al.} \mathrm{(2014)}$ found similar results, with increase of $61 \%$ in $A A C$ in common bean leaves at the beginning of reproductive stage, using leaf applications of bioestimulant based on cytokinin, acid indole butyric acid, and gibberellic acid.

Tuna et al. (2010) found an increase of $63.9 \%$ in proline contents in leaves of a yellow melon cultivar subjected to ID of $50 \%$ field capacity in relation to the control (100\% field capacity). Thus, plants increase the production of these compounds to improve tolerance to water stress.

In the cold season, AAC increased under ID from $60 \%$ to $100 \%$ ETC, and decreased under ID of $120 \%$ ETc, except when using BTM of $4.8 \mathrm{~L} \mathrm{ha}^{-1}$ (Figure 6F). The highest AAC (0.097 $\left.\mathrm{mg} \mathrm{g}^{-1}\right)$ was found for the ID of $100 \%$ with BTM of $2.4 \mathrm{~L} \mathrm{ha}^{-1}$. Thus, environmental stress due to climate condition at planting time increases AAC.

Castro \& Carvalho (2014) founded that the application of AAC can increase the synthesis of proteins in agricultural crops, promote higher tolerance to stress, and form intermediate compounds of plant hormones, which may have occurred in the present work. The mean TSS, RS, and AAC were higher in the hot season (Figure 7). Thus, differences in temperature, relative humidity, and solar radiation found in the different crop seasons contributed to the variations in photosynthetic activity and, consequently, affected carbohydrate production and amino acid synthesis processes.
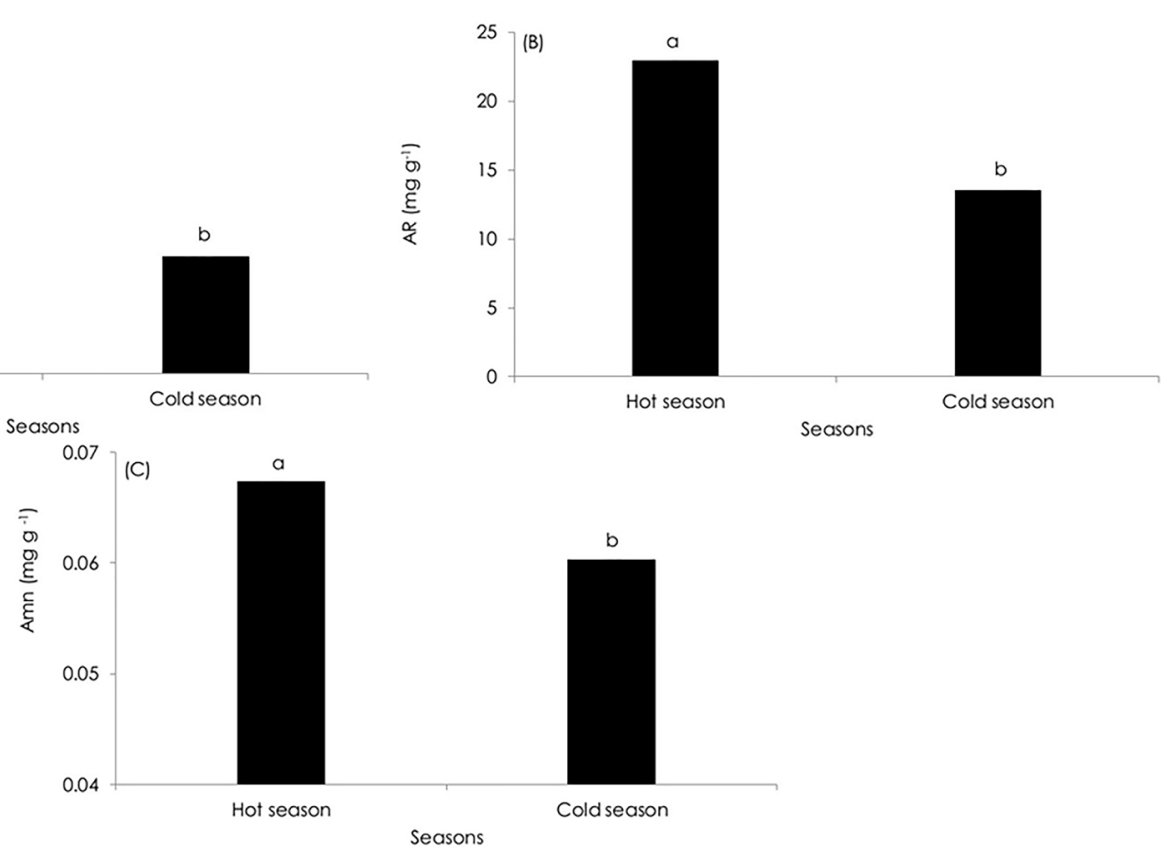

Seasons

Figure 7. Total soluble sugars (TSS), reducing sugars (RS), and amino acid (AAC) contents in Pele de sapo melon plants grown under different irrigation depths and bioestimulant rates in the hot and cold seasons. 
The saccharose is used as an energy source and substrate for several metabolic process by most plant species, including melon. The amounts of saccharose found were $36.98 \mathrm{mg} \mathrm{g}^{-1}$ for the hot season, and 42.88 $\mathrm{mg} \mathrm{g}^{-1}$ for the cold season. The sugar translocation in the plant could probably be lower in the hot season due to the higher saccharose accumulation in the leaf.
This indicates that the plant had a lower physiological performance than those in the hot season.

The interaction between ID and BTM was significant for fruit yield in both crop seasons (Figure 8). In the hot season, the BTM of $4.8 \mathrm{~L} \mathrm{ha}^{-1}$ with ID of $120 \%$ ETC resulted in plants with higher total (approximately 2 fruits) and commercial (1 fruit) number of fruits per plant.
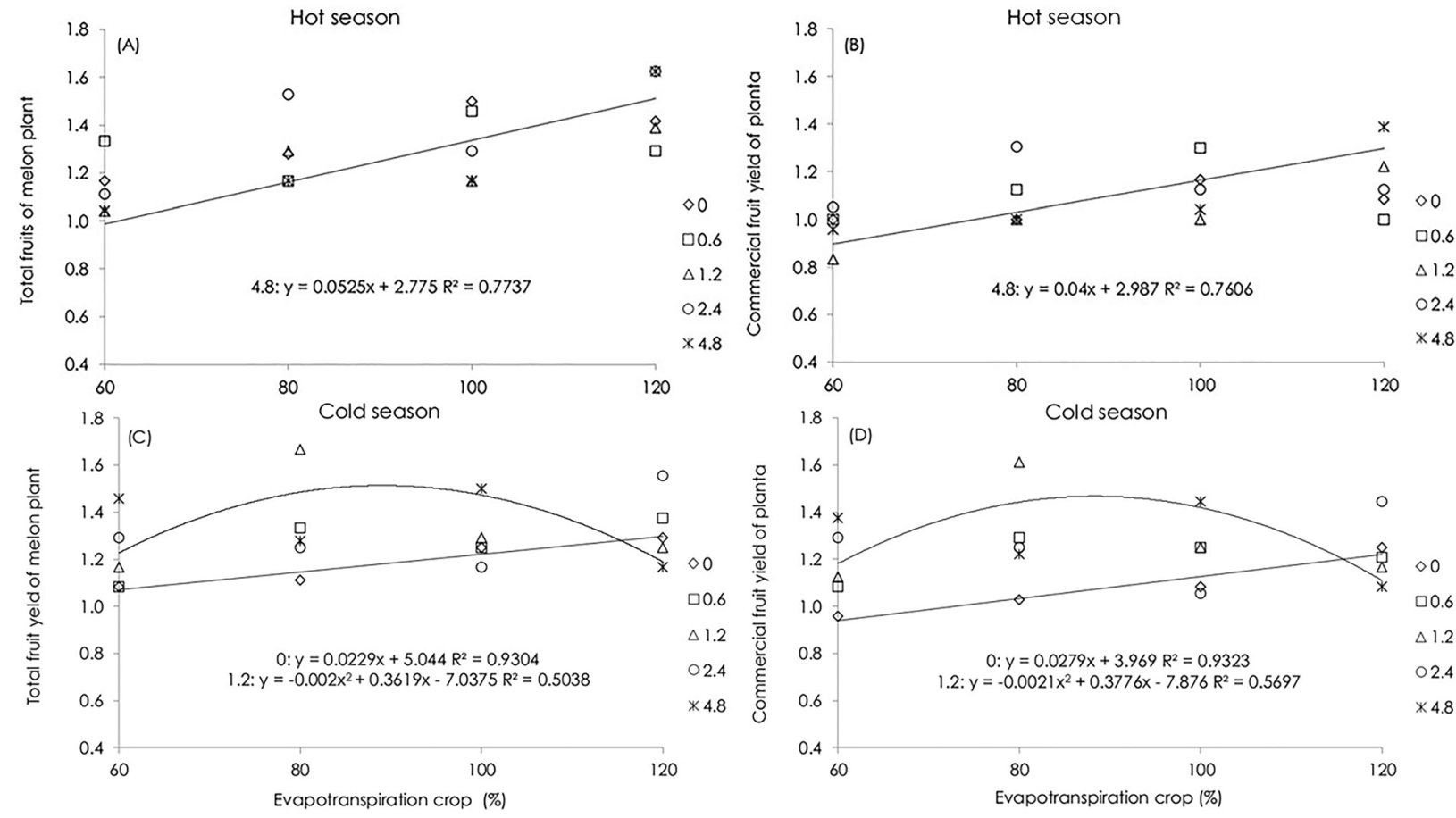

Figure 8. Total and commercial fruit yield of Pele de sapo melon plants grown under different irrigation depths and bioestimulant rates in the hot ( $A$ and $B$ ) and cold ( $C$ and $D$ ) seasons.

In the cold season, fruit yield was higher for the BTM of $1.2 \mathrm{~L} \mathrm{ha}^{-1}$ with ID of $90 \%$ ETC, showing approximately 2 fruits for total and commercial yield per plant. These results can be related to increases in photosynthetic rate in both crop seasons, which resulted in higher metabolic performance of plants and, consequently, increases in fruit yield.

\section{Conclusions}

The use of bioestimulant rates of $2.4 \mathrm{~L} \mathrm{ha}^{-1}$ in the hot season and $4.8 \mathrm{~L} \mathrm{ha}^{-1}$ in the cold season, combined with the use of an irrigation depth of $120 \%$ ETc, resulted in plants with higher photosynthetic activity and relative water content.

The irrigation depth of $60 \%$ ETc resulted in water stress, decreasing gas exchange rates and increasing solute (total soluble sugar) concentration in both crop seasons evaluated.

The hot season (September to November), irrigation depth of $120 \%$ ETC, and bioestimulant rate of $2.4 \mathrm{~L} \mathrm{ha}^{-1}$ are recommended for the grown of Pele de sapo melon, because the plants presented better physiological performance and mean fruit yield of 1 fruit per plant under these conditions.

\section{References}

Abrantes, F.L., Sá, M.E., Souza, L.C.D., Silva, M.P., Simidu, H.M., Andreotii, M., Buzetti, S., Valério Filho, W.V., Arruda, N. 2011. Uso de regulador de crescimento em cultivares de feijão de inverno. Pesquisa Agropecuária Tropical 41: 148-154.

Almeida, Q.A., Soratto, R.P., Broetto, F., Cataneo, A.C. 2014. Nodulação, aspectos bioquímicos, crescimento e produtividade do feijoeiro em função da aplicação de bioestimulante. Semina: Ciências Agrárias 35: 77-88.

Araújo, J.L.P., Assis, J.S., Costa, N.D., Pinto, J.M., Dias, R.C.S., Silva, C.M.J. 2008. Produção integrada de melão no Vale do São Francisco: manejo e aspectos socioeconômicos. In: Braga Sobrinho, R., Guimarães, J.A., Freitas, J.A.D., Terao, D. (Ed.). Produção integrada de melão. Embrapa Agroindústria Tropical: Banco do Nordeste do Brasil, Fortaleza, Brazil. p. 43-50.

Araújo, S.A.C, Deminicis, B.B. 2009. Fotoinibição da Fotossíntese. Revista Brasileira de Biociências 7: 463-472.

Beltrano, J., Ronco, M.G. 2008. Improved tolerance of wheat plants (Triticum aestivum L.) to drought stress and 
rewatering by the arbuscular mycorrhizal fungus Glomus claroideum: effect on growth and cell membrane stability. Brazilian Journal of Plant Physiology 20: 29-37.

Calvo, P., Nelson, L., Kloepper, J.W. 2014. Agricultural uses of plant biostimulants. Plant and Soil 383: 3-41.

Castro, P.R., Carvalho, M.E.A. 2014. Aminoácidos e suas aplicações na agricultura. Série Produtor Rural, Piracicaba, Brazil. 58 p.

Câmara, M.J.T., Negreiros, Z.M., Medeiros, F.J., Neto, B.F., Junior, B.P.A. 2007. Produção e qualidade de melão amarelo influenciado por coberturas do solo e lâminas de irrigação no período chuvoso. Ciência Rural 37: 58-63.

Chaves, A.R.M., Pinto, J.M., Aidar, S.T. 2015. Trocas gasosas e produtividade de meloeiros cultivados sob agrotêxteis e a pleno sol. Embrapa, Petrolina, Brazil. 21 p.

Cocking, E.C., Yemm, E.W. 1954. Estimation of amino acids by ninhydrin. The Biochemical Journal 58: xii.

Costa, N.D. 2008. A cultura do melão. Coleção Plantar, Brasília, Brazil. $191 \mathrm{p}$.

Dalastra, M.G., Echer, M.M., Guimarães, V.F., Hachmann, T.L., Inagaki, A.M. 2014. Trocas gasosas e produtividade de três cultivares de meloeiro conduzidas com um e dois frutos por planta. Bragantia 73: 365-371.

Dantas, I.C., Oliveira, W.C., Silva, L.F., Santos, S.S.F., Marco, A.C. 2013. Produção de melão amarelo sob diferentes densidades de plantio. Revista Brasileira de Agricultura Irrigada 7: 74-84.

Ferreira, D.F. 2011 . Sisvar: a computer statistical analysis system. Ciência e Agrotecnologia 35: 1039-1042.

Figueirêdo, M.C.B., Gondim, R.S., Aragão, F.A.S. 2017. Produção de melão e mudanças climáticas: sistemas conservacionistas de cultivo para redução das pegadas de carbono e hídrica. Embrapa Agroindústria Tropical Livro técnico, Brasília, Brazil. 302 p.

Lechinoski, A., Freitas, J.M.N., Castro, D.S., Lobato, A.K.S., Oliveira Neto, C.F., Cunha, R.L.M., Costas, R.C.L. 2007. Influência do estresse hídrico nos teores de proteínas e aminoácidos solúveis totais em folhas de Teca (Tectona grandis L. f). Revista Brasileira de Biociências 5: 927-929.

Lopes, I. 2014. Crescimento e qualidade tecnológica da cana-de-açúcar em função da aplicação de bioestimulante. 50p. (Trabalho de Conclusão de Curso - Monografia) - Universidade Federal do Vale do São Francisco, Juazeiro, Brazil.

Machado, D.F.S.P., Machado, E.C., Machado, R.S., Ribeiro, R.V. 2010. Efeito da baixa temperatura noturna e do porta-enxerto na variação diurna das trocas gasosas e na atividade fotoquímica de laranjeira 'Valência'. Revista Brasileira de Fruticultura 32: 351-359.

Machado, D.F.S.P., Lagôa, A.M.M.A., Ribeiro, R.V., Marchiori, P.E.R., Machado, R.S., Machado, E.C. 2013. Baixa temperatura noturna e deficiência hídrica na fotossíntese de cana-de-açúcar. Pesquisa Agropecuária
Brasileira 48: 487-495.

Marenco, R.A., Lopes, N.F. 2009. Fisiologia Vegetal: fotossíntese, respiração, relações hídricas e nutrição mineral. UFV, Viçosa, Brazil. 486 p.

Miller, G.L. 1959. Use of dinitrosalicylis acid reagent for determination of reducing sugars. Analytical Chemistry 31: 426-428.

Miranda, F.R., Bleicher, E. 2001. Evapotranspiração e coeficientes de cultivo e de irrigação para a cultura do melão (Cucumis melo L.) na região litorânea do Ceará. Embrapa, Fortaleza, Brazil. 17 p.

Moris, D.L. 1948. Quantitative determination of carbohydrates with Drywood's anthrone reagent. Science 107: 254-255.

Pereira, J.W.L., Melo Filho, P.A., Albuquerque, M.B., Nogueira, R.J.M.C., Santos, R.C. 2012. Mudanças bioquímicas em genótipos de amendoim submetidos a déficit hídrico moderado. Revista Ciência Agronômica 43: 766-773.

Silva, F.G., Dutra, W.F., Dutra, A.F., Oliveira, I.M., Filgueiras, L.M.B., Melo, A.S. 2015. Trocas gasosas e fluorescência da clorofila em plantas de berinjela sob lâminas de irrigação. Revista Brasileira de Engenharia Agrícola e Ambiental 19: 946-952.

Soares, L.A.A., Lima, G.S., Brito, M.E.B., Sá, F.V.S., Silva, E.C.B., Araújo, T.T. 2012. Cultivo do tomateiro na fase vegetativa sobre diferentes lâminas de irrigação em ambiente protegido. Agropecuária Científica no Semiárido 8: 38-45.

Suassuna, F.J., Melo, A.S., Costa, F.S., Fernandes, P.D., Ferreira, R.S., Sousa, M.S.S. 2011. Eficiência fotoquímica e produtividade de frutos de meloeiro cultivado sob diferentes lâminas de irrigação. Semina: Ciências Agrárias 32: $1251-1262$.

Tuna, A.L., Kaya, C., Ashraf, M. 2010. Potassium sulfate improves water deficit tolerance in melon plants grown under glasshouse conditions. Journal of Plant Nutrition 33: 1276-1286.

Yemm, E.W., Willis, A.J. 1954. The estimation of carbohydrates in plants extracts by anthrone. Biochemical Journal 57: 508-514.

Conflict of Interest Statement: The authors declare that the research was conducted in the absence of any commercial or financial relationships that could be construed as a potential conflict of interest.

All the contents of this journal, except where otherwise noted, is licensed under a Creative Commons Attribution License attribuition-type BY. 